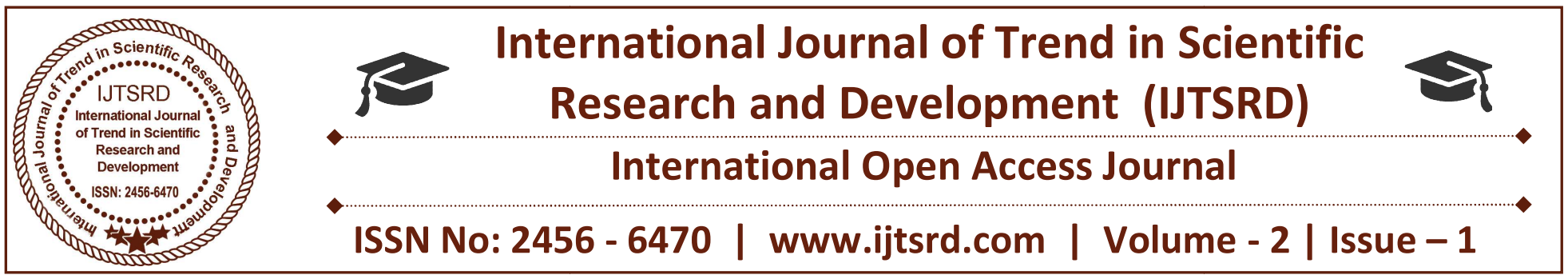

\title{
A Study of Relationship Between Personality and Learning Stress among Students
}

\author{
Pragya Singh \\ Research Scholar, Department of Education, \\ University of Allahabad
}

\author{
Prof. K.S.Misra \\ Superviser, Department of Education, \\ University of Allahabad
}

\section{ABSTRACT}

Learning stress is one of the biggest problems among the students in present scenario. It becomes very injurious many times for students mental and physical health. The objective of the present study is to find out the relationship between learning stress and personality traits among students. The sample of 89 students of class XI students was taken from two institutions of the city. Two tools named 'Learning Stress Scale' and 'Personality Inventory' has been used. Correlaional method of research has been used. To find out the relationship between learning stress and personality product moment correlation has been analyze the data. Results of the study show a negative relationship was found between learning stress and assertive, more analytical and confident trait of personality on the other hand humble, less analytical and apprehensive traits of personality are positively correlated with learning stress. Students who are assertive, more analytical and confident feel less learning stress but students who are humble, less analytical and apprehensive feel more stress. Study also does not find any relationship between learning stress and experimenting, emotionally stable, sociable, more inquisitive, relaxed, persistent, supportive, independent, enthusiastic, forthright, divergent, dominant, adaptive, spiritual, affectionate, self-critical and conscientious traits of personality.

\section{A STUDY OF RELATIONSHIP BETWEEN PERSONALITY AND LEARNING STRESS AMONG STUDENTS}

Now a day's learning stress has become a matter of concern for the students. Physiological and psychological changes occurring during engagement in learning events can cause or aggravate learning stress. The rising expectations of the parents in terms of academic performance usually put extra burden on children, it may sometimes cause many physical or mental ailments, if not dealt effectively. But academic stress has an adverse effect on the mental health of adolescents. Learning stress is result of challenges of a learning situations and student ability and efforts to meet with them. When student's aspirations are too high to reach but his abilities, interests, attitudes and capacities do not match with it, the students develop stress. This stress may cause different types of physical or mental problems

Personality variables also affect people's reaction to potential stressors. Personality can be a main source of variation in the arousal of stress and its affect on human functioning. It determines the way an individual evaluates the personal significance of what is happening in and outside the classroom. Researches have been taken place to understand the relationship between anxiety and personality. The need to know about the relationship between learning stress and personality encouraged researcher to take this topic for study. Amanda et al, 2013, conducted a study on academic major, personality type and stress among college students, No difference in personality traits was found between different majors, stress correlated positively with neuroticism, but did not correlate with any other personality traits, neuroticism correlated negatively with extraversion.

An article written by Carver and Connor-Smith (2010) explored if people with different personality types use different coping mechanisms. Individuals 
that are considered extraverted are characterized as sociable, energetic, and assertive. Due to their sociability, extraverted people tend to have stronger support systems in times of difficulty. They often view stressful events as challenges. Conscientious individuals, characterized as self-disciplined and persistent, they engage in problem-solving as a proactive method of coping. In addition, conscientious people tend to be less impulsive and avoid engaging in risky behaviour that could lead to stress. In comparison, neurotic individuals are prone to feeling anxious, sad, and distressed when problems arise. Rather than dealing with problems head on, neurotic individuals tend to avoid finding solutions. A study done by Ebstrup, Eplov, Pisinger, and Jorgensen (2011) used the perceived stress scale and the NEO five-factor inventory to determine the relationship between different personality types and stress. The researchers found a positive correlation between neuroticism and stress, they found a moderate negative relationship between extraversion and stress. There was a moderate negative correlation between conscientiousness and stress.

\section{OBJECTIVES OF THE STUDY-}

The objective of the study is-

To find out the relationship between learning stress and personality.

\section{HYPOTHESIS OF THE STUDY-}

It was hypothesized that-

$>$ There is no significant relationship between learning stress and personality.

\section{METHODOLOGY-}

SAMPLE- Secondary school students of aided schools of Allahabad city constitute the population for this study. From the population a sample of 100, XI class students of two institutions was taken as a sample.

TOOLS- Two tools has been used for data collection. For measuring learning stress among students, 'Learning stress scale' developed by 'K.S.Misra' has been used. For measuring personality of students, 'Personality inventory' made by K.S.Misra has been used.

STATISTICS USED- Correlational method of research has been used. To find out the relationship between learning stress and personality product moment correlation has been used to analyze the data.

Results - Table 1 shows value of Product moment correlation was used to calculate the correlation between learning stress and 20 personality traits and -

Table-1 Correlations between personality traits and learning stress

\begin{tabular}{|c|c|c|c|}
\hline Sr.no & Personality traits & $\mathbf{N}$ & $\mathbf{R}$ \\
\hline 1. & $\begin{array}{l}\text { Experimenting vs } \\
\text { Conventional }\end{array}$ & 89 & -.086 \\
\hline 2. & $\begin{array}{l}\text { Emotionally stable vs } \\
\text { Excitable }\end{array}$ & 89 & -.170 \\
\hline 3. & $\begin{array}{ll}\text { Spiritual } & \text { vs } \\
\text { Materialist } & \end{array}$ & 89 & -.021 \\
\hline 4. & Adaptive vs Rigid & 89 & .041 \\
\hline 5. & $\begin{array}{ll}\text { Confident } & \text { vs } \\
\text { Apprehensive }\end{array}$ & 89 & $-.310 * *$ \\
\hline 6. & $\begin{array}{l}\text { More inquisitive vs } \\
\text { less inquisitive }\end{array}$ & 89 & .092 \\
\hline 7. & Relaxed vs Tense & 89 & -.188 \\
\hline 8. & $\begin{array}{l}\text { Affectionate } \\
\text { Undemonstrative }\end{array}$ & 89 & -.175 \\
\hline 9. & Persistent vs Casual & 89 & -.175 \\
\hline 10. & $\begin{array}{ll}\text { Self-critical } & \text { vs } \\
\text { Happy-go-lucky }\end{array}$ & 89 & -.130 \\
\hline 11. & $\begin{array}{l}\text { Supportive } \\
\text { Inhibitive }\end{array}$ & 89 & -.107 \\
\hline 12. & $\begin{array}{ll}\text { Independent } & \text { vs } \\
\text { Group dependent }\end{array}$ & 89 & -.130 \\
\hline 13. & $\begin{array}{l}\text { Enthusiastic } \quad \text { vs } \\
\text { Lethargic }\end{array}$ & 89 & -.107 \\
\hline 14. & Assertive vs Humble & 89 & $-.263 *$ \\
\hline 15. & $\begin{array}{l}\text { More analytical vs } \\
\text { Less analytical }\end{array}$ & 89 & $-.242 *$ \\
\hline 16. & $\begin{array}{l}\text { Forthright } \\
\text { Crooked }\end{array}$ & 89 & -.105 \\
\hline 17. & $\begin{array}{l}\text { Divergent } \\
\text { Convergent }\end{array}$ & 89 & -.127 \\
\hline 18. & $\begin{array}{l}\text { Dominant } \\
\text { Submissive }\end{array}$ & 89 & -.106 \\
\hline 19. & $\begin{array}{l}\text { Conscientious } \\
\text { Unscrupulous }\end{array}$ & 89 & .068 \\
\hline 20. & $\begin{array}{l}\begin{array}{l}\text { Social vs } \\
\text { centered }\end{array} \\
\text { Self- }\end{array}$ & 89 & -.119 \\
\hline
\end{tabular}

$* / * *$ significant at $\mathbf{0 5 / . 0 1}$ level.

Observation of table 1 shows that the value of coefficient of correlation between learning stress and 
Assertive vs humble (r- .263) and more analytical vs less analytical (r-.242) are significant at 0.05 level. Values of coefficient of correlation between learning stress and Confident vs apprehensive ( $\mathrm{r}-.310)$ is significant at 0.01 level. It means learning stress is negatively related to personality traits named assertive, more analytical and confident but it is positively apprehensive, less analytical and humble. Table 1 also reveals that the coefficient of correlation between remaining 17 traits of personality and learning stress are not significant at 0.05 level. It means learning stress is not related to personality traits named experimenting, emotionally stable, sociable, more inquisitive, relaxed, persistent, supportive, independent, enthusiastic, forthright, divergent, dominant, adaptive, spiritual, affectionate, self-critical and conscientious.

Results shows that students who are more assertive feel less learning stress, it is possible because assertive students are able to correctly express their opinions as well as defend their point of view before there teachers, they get confidence through this and get able to solve their problems through discussion with teachers and classmates, assertive students use to listen things actively in the classroom, so that they may be able to represent themselves very well, thus they gain more knowledge and confidence, which lead them to feel low level of stress, on the opposite end of scale humble students are not confident in themselves and don't see the value of their work, sometimes being too humble and letting others take credit for their work can make them seem incompetent, this all situations lead high learning stress in students. Confidant students are self motivated, intellectual, self-managed, focused, committed, pragmatic and persistent. They have no doubt about their tasks, they are risk taker and takes the responsibilities of their own failure and learn from it, because they have faith on themselves. These all qualities decrease their learning stress, but Apprehensive students are always anxious/fearful that something bad or unpleasant will happen, so they are unable to solve their problems, they are nervous enough for doing any experiment with their studies, their thinking lead their adverse situations to let it be as it is, and these all things can be a reason of increased learning stress in them. More analytical students are very knowledgeable, they are critical thinker, have power to think about the things deeply. So they are able to learn easily then parrotry. They are creative, and all this lead them to low level of learning stress, at the opposite end of the scale Less Analytical students have to ingeminate their syllabus, for scoring in the examination, they are unable to think critically, so they feel problem in answering application based questions, they are unable to find out the right solutions of the problems, so these type of students have more stress.

\section{CONCLUSION}

The objective of the study was to find out the relationship between learning stress and personality, the results shows a positive relationship between the three personality traits name less analytical, apprehensive and humble, whether negative correlation is find out between learning stress and assertive, confident and more analytical traits of personality. Remaining 17 personality traits do not show any correlation with learning stress. Previous Study of Ebstrup, J., et al (2011) has shown a moderate negative correlation between conscientious and stress, but the results of the study are contradictory to it, as no any relationship was found between learning stress and conscientious. The result that assertiveness is negatively related to learning stress support the study of Carver et al(2010) who found a negative correlation between assertive trait of personality and learning stress.

\section{REFERENCES}

1) Amanda Allred, Megan Granger, Tyler Hogstrom,2013, The relationship Between academic major, personality type, and stress in college Students, https:// retrieved from www.education.com/reference/article/anxietyclassroom vol 9 on 12.9.2017.

2) Carver, C.S., \& Connor-Smith, J. (2010). Personality and coping. Annual Review of Psychology, 61, 679-704.

3) Ebstrup, J., Eplov, L., Pisinger, C., \& Jorgensen, T. (2011), Association between the five factor personality traits and perceived stress: Is the effect mediated by general self-efficacy? Anxiety, Stress, \& Coping: An International Journal, 24(4), 407-419.

4) Garrett. H.E.,(2012) Statistics in Psychology and Education. Bombey: Vakil feffer Simons Ltd.

5) Voichita M. Dumitru, and Doina Cozman 2012, The relationship between stress and personality factors. Veterinary Medicine International Journal of the Bioflux Society. Retrieved from https://www.education.com/reference/article/anxie ty-classroom.

6) shodhganga.inflibnet.ac.in 